TITLE:

\title{
Month of birth in multiple sclerosis with and without longitudinally extensive spinal cord lesions: A study of a Japanese national survey.
}

\section{AUTHOR(S):}

Araki, Yasukiyo; Kinoshita, Masako; Motoyama, Rie; Matsushita, Takuya; Nakagawa, Masanori; Kira, Jun-Ichi; Tanaka, Masami

\section{CITATION:}

Araki, Yasukiyo ...[et al]. Month of birth in multiple sclerosis with and without longitudinally extensive spinal cord lesions: A study of a Japanese national survey.. Journal of the neurological sciences 2013, 330(1-2): 67-70

ISSUE DATE:

2013-07-15

URL:

http://hdl.handle.net/2433/175251

\section{RIGHT:}

(c) 2013 Elsevier B.V.; この論文は出版社版でありません。引用の際には 出版社版をご確認ご利用ください。; This is not the published version. Please cite only the published version. 


\section{Journal of the Neurological Sciences}

\section{Clinical Research Paper}

\section{Title}

Month of birth in multiple sclerosis with and without longitudinally extensive spinal cord lesions: A study of a Japanese national survey

\section{Authors}

Yasukiyo Araki, ${ }^{1}{ }^{2}$ Masako Kinoshita, ${ }^{3}$ Rie Motoyama, ${ }^{1}$ Takuya Matsushita, ${ }^{4}$ Masanori Nakagawa, ${ }^{2}$ Jun-ichi Kira, ${ }^{4}$ Masami Tanaka ${ }^{1}$

\section{Affiliations}

1. MS Center, Utano National Hospital, National Hospital Organization, Kyoto, Japan

2. Department of Neurology, Kyoto Prefectural University of Medicine, Kyoto, Japan

3. Department of Neurology, Utano National Hospital, National Hospital Organization, Kyoto, Japan

4. Department of Neurology, Neurological Institute, Graduate School of Medical Science, Kyushu University, Fukuoka, Japan 


\section{Corresponding Author}

Masako Kinoshita, M.D., Ph.D.

Department of Neurology

Utano National Hospital, National Hospital Organization

8 Ondoyama-Cho, Narutaki, Ukyoku

Kyoto 616-8255, Japan

Tel: +81-75-461-5121

Fax: +81-75-464-0027

E-mail: machak@kuhp.kyoto-u.ac.jp

\section{Key Words}

Multiple sclerosis; Month of birth; Longitudinally extensive spinal cord lesions; Environmental

factors; Cohort study; Prevalence 


\section{Abstract}

Objectives: Month of birth has been associated with the environmental factors for multiple sclerosis (MS). This study aimed to investigate whether individuals with MS had significantly different frequencies of birth in a particular month of the year, and whether month-of-birth patterns were influenced by the longitudinally extensive spinal cord lesions (LESCL) status relative to the general population in the same Japanese birth cohort.

Methods: In this study, performed as a part of the fourth Japanese nationwide survey of MS, patients were divided into two groups according to the presence $(n=307)$ or absence $(n=906)$ of LESCLs that were diagnosed on the basis of magnetic resonance imaging findings. The number of births in every month was counted for both groups. Control data were obtained from birth records of the Japanese general population of the median years of birth of each group. Differences in the month-of-birth distributions between the patients and the general population were assessed using the chi-square test.

Results: In MS patients without LESCLs, significantly more patients were born in January and June, whereas significantly fewer patients were born in May, compared to the general population. The seasonal patterns of birth were not in association with those of ambient ultraviolet (UV) radiation. No significant differences were found for the month-of-birth distributions between MS patients with LESCLs and the general population. 
Conclusions: A different distribution of month of birth in Japanese MS patients without LESCLs from the general population, but not in those with LESCLs, suggests some role for environmental factors in the pathogenesis of the former group. Environmental factors other than UV radiation should be further elucidated in Japanese and other Asian MS cohorts. 


\section{Introduction}

It is widely believed that multiple sclerosis (MS) results from the interplay between

environmental and genetic factors. (1) Strong evidence connects environmental factors such as latitude of birthplace, Epstein-Barr virus (EBV) exposure, smoking, and vitamin D deficiency with MS. (2-10) The investigation of seasonal birth patterns is one of the classic

epidemiological approaches to seek the early-life environmental influences on disease process and to suggest seasonally-variable risk factors. (11) Seasonal birth patterns in MS, epilepsy, and amyotrophic lateral sclerosis patients vary from the general population. (11-22) Previous studies, primarily from northern/western countries, suggest that birth in spring and summer is associated with a subsequent occurrence of MS. (11-19) A study of seasonal birth patterns for a certain disease in areas with different seasonality can potentially add new information about environmental factors associated with that disease. Japan is generally a rainy country with high humidity, has four distinct seasons and the marked rainy season, and has a variety of climates because of its wide range of latitude stretching from $24^{\circ}$ to $46^{\circ} \mathrm{N}$. The temperature fluctuates between extremes, ranging from freezing in the winter to sweltering in the summer.

Compared with MS patients in Europe, MS patients in Japan are characterized by more frequent involvement of the spinal cord and binocular optic nerve, leading to severe visual impairment at disease onset; however, the cerebellum is less frequently involved. (23) After the 
discovery of anti-aquaporin 4 antibodies in 2004, these manifestations were often shown to be associated with neuromyelitis optica (NMO), characterized by severe optic neuritis, and longitudinally extensive spinal cord lesions (LESCLs) extending over three or more vertebral segments. $(24,25)$

To investigate the role of environmental factors in Asian MS patients whose clinical manifestations differ from those of Western MS patients, we evaluated whether the month-of-birth effects found in Western MS patients could be also found in Japanese MS patients, with special emphasis on the presence or absence of LESCLs.

\section{Methods}

Survey procedures

This study was performed as part of the fourth nationwide survey of Japanese MS, which was conducted by the Research Committees of Neuroimmunological Diseases and of Epidemiology of Intractable Diseases, sponsored by the Ministry of Health, Labour and Welfare, Japan. The study was approved by the Kyushu University Ethics Committee. The general findings of the survey have been reported previously. $(26,27)$ In brief, the survey was undertaken in the following two steps: first, a preliminary survey was undertaken to ascertain the approximate 
number of MS patients in Japan and second, a survey was conducted using a questionnaire sheet for each patient. The hospitals randomly selected from the directory of all of the registered hospitals throughout Japan were included in the study. The study also included all university hospitals, in which council members of the Japanese Society of Neurology and members of the Committees of Medical Facilities for Children and the Japanese Society of Child Neurology practiced. In January 2004, a preliminary survey questionnaire for MS patients who visited hospitals because of MS from 1 January 2003 to 31 December 2003 was mailed to 6708 departments together with the diagnostic criteria. A second questionnaire was forwarded to those institutions who reported patients during the first survey. The second survey requested detailed clinical information on individual patients, including age at onset and examination, sex, birthplace, present address, symptoms based on history and signs based on physical examination, laboratory findings, course, treatment and prognosis. Patients who were reported by more than one hospital or department were treated as duplicates, and when discordance occurred between data sources, the earliest data of the patient were used. The patients were divided into two groups according to the presence or absence of LESCLs on the basis of magnetic resonance imaging (MRI) findings, to ascertain whether individuals with MS had significantly different frequencies of birth in the months of the year relative to the general population in the same birth cohort and whether this differed according to the LESCLs status. The two groups were further 
subdivided on the basis of sex and birthplace location (i.e. north or south) relative to the approximate midpoint $\left(37^{\circ} \mathrm{N}\right)$ of the mainland. (27) The number of birth in every month was counted about each patient group.

Control data of the Japanese general population were obtained from the national vital statistics of the Japanese government agencies available from 1972 to 1997. (28) The total number of births and their annual monthly distribution corresponding to the median year of birth in each group served as the control data.

\section{Diagnostic criteria}

The diagnostic criteria for MS in the present survey were as follows: [1] symptoms and signs owing to multifocal inflammatory lesions in the CNS (dissemination in space); [2] remissions and exacerbations (dissemination in time); and [3] other diseases such as acute disseminated encephalomyelitis were excluded. (26) Although the diagnostic criteria were originally adopted for clinically definite MS, they were also applicable in patients with NMO. At the time of the survey in 2004, we were unable to measure anti-aquaporin 4 antibodies or exclude patients with NMO.

MRI finding-based classification 
In the present study, patients were divided into subgroups according to the presence or absence of LESCLs on the basis of MRI findings-based classification as previously described. $(13,26)$ LESCLs were defined as those extending over three or more vertebral segments in MRIs performed during the entire clinical course.

\section{Statistical analysis}

We examined the null hypothesis that the monthly birth rate in each patient group did not differ from that in the Japanese general population. The chi-square test (Microsoft Excel 2010, Microsoft Japan, Tokyo) was used and the significance level was set at $\mathrm{p}=0.05$.

\section{Results}

Data for birth year and birth month were available for 1,213 MS patients born between 1927 and 1997. The median year of birth of the group of patients without LESCLs was 1964, whereas that of the group of patients with LESCLs was 1957. The total number of births in Japan and the annual birth month distribution are shown in Table 1.

Relative to the general population, patients without LESCLs $(n=906)$ showed a significantly increased frequency of birth in January and June and decreased frequency of birth in May (Table 2). In addition, patients without LESCLs had a statistically insignificant trend 
towards a lower birth rate tendency in October (autumn) and higher birth rate in August (summer). In contrast, no difference in month-of-birth distribution was found between MS patients with LESCLs $(\mathrm{n}=307)$ and the general population (Table 3).

In patients without LESCLs (250 males and 656 females), male patients were significantly more frequently born in June (Table 4), whereas females patients were more frequently born in January and less frequently in May (Table 5), compared with the general population. Birthplace information was obtained for 711 patients without LESCLs (306 northern born and 405 southern born). Compared with the general population, a significant more number of northern-born patients were born in January and fewer in November (Table 6), whereas fewer southern-born patients were born in May (Table 7).

\section{Discussion}

The present study of Japanese MS patients has identified a significantly different month-of-birth pattern in MS patients without LESCLs, but not in those with LESCLs, compared with the general population. To the best of our knowledge, this is the first study to demonstrate a difference in the month-of-birth pattern for persons with MS without LESCLs from the general population, suggesting some role for environmental factors in this group. 
In our study, MS patients without LESCLs were born more frequently in January and less frequently in May, compared with the general population. Japan is at a lower latitude than European countries and the seasonal solar radiation widely varies; solar ultraviolet (UV) radiation is the lowest in January and a long spell of fine weather lasts in May with the maximum global solar radiation. (29)

Varying seasonal maternal epidermal exposure to solar UV radiation and subsequent synthesis of the hormonally active metabolite 1,25-dihydroxyvitamin D during gestation is one of the theorized pathways of the month of birth to cause MS. $(6,10,30)$ Previous studies in Europe and Australia have demonstrated that early gestation during winter months and birth during summer months are associated with an increased frequency of subsequent MS, whereas early gestation during summer months and birth during winter months are associated with a decreased frequency of subsequent MS. (11-19) However, data of the present study are in conflict with those reported in previous studies. In addition, the monthly birth distribution pattern in the present study differs from a sinusoidal pattern that is known to be in agreement with seasonal UV changes. (19) Although our data reflect a similar tendency of increased birth frequency of MS patients without LESCLs in June and August and decreased birth frequency in October, and also in November in northern-born patients, our data suggest a need to consider other kind of environmental factors. 
Considering the inconsistent direction of effect and absence of a particular seasonal

effect identified by previous studies in this area, the possible role of the type 1 error to explain our findings cannot be dismissed. One limitation of the current study is the possible inclusion of NMO cases in the cohort. Unlike MS, no UV effect for NMO has been identified in the literature; therefore inclusion of these cases may have obscured any possible month-of-birth effect.

In conclusion, the present study finds some evidence for a month-of-birth effect for MS patients without LESCLs in Japan; however the pattern of month-of-birth in this group was not explicable by a seasonal UV pattern as found in previous studies. Further research is required to elucidate whether a role exists for environmental factors in the aetiology of MS in Asian populations. 


\section{Acknowledgements}

This study was supported in part by the Health and Labour Sciences Research Grants for

research on intractable diseases, and by grants from the Research Committees of

Neuroimmunological Diseases and of Epidemiology of Intractable Diseases, from the Ministry

of Health, Labour and Welfare of Japan. 


\section{References}

[1] Willer CJ, Ebers GC. Susceptibility to multiple sclerosis: interplay between genes and environment. Curr Opin Neurol 2000;13:241-247.

[2] Ramagopalan SV, Valdar W, Dyment DA, DeLuca GC, Yee IM, Giovannoni G, et al. Association of infectious Mononucleosis with multiple sclerosis. A population-based study. Neuroepidemiology 2009;32:257-262.

[3] Disanto G, Pakpoor J, Morahan JM, Hall C, Meier UC, Giovannoni G, et al. Epstein-Barr virus, latitude and multiple sclerosis. Mult Scler 2012;19:362-365.

[4] Handel AE, Williamson AJ, Disanto G, Handunnetthi L, Giovannoni G, Ramagopalan SV. An updated meta-analysis of risk of multiple sclerosis following infectious mononucleosis. PLoS One 2010;5:e12496.

[5] Hawkes CH. Smoking is a risk factor for multiple sclerosis: a metanalysis. Mult Scler 2007;13:610-615.

[6] Wallin MT, Page WF, Kurtzke JF. Multiple sclerosis in US veterans of the Vietnam era and later military service: race, sex, and geography. Ann Neurol 2004;55:65-71.

[7] Simpson S Jr, Blizzard L, Otahal P, Van der Mei I, Taylor B. Latitude is significantly associated with the prevalence of multiple sclerosis: a meta-analysis. J Neurol Neurosurg Psychiatry 2011;82:1132-1141. 
[8] Koch-Henriksen N, Sørensen PS. The changing demographic pattern of multiple sclerosis epidemiology. Lancet Neurol 2010;9:520-532.

[9] Taylor BV, Pearson JF, Clarke G, Mason DF, Abernethy DA, Willoughby E, et al. MS prevalence in New Zealand, an ethnically and latitudinally diverse country. Mult Scler 2010;16:1422-1431.

[10] Kampman MT, Brustad M. Vitamin D: a candidate for the environmental effect in multiple sclerosis-observations from Norway. Neuroepidemiology 2008;30:140-146.

[11] Templer DI, Trent NH, Spencer DA, Trent A, Corgiat MD, Mortensen PB, et al. Season of birth in multiple sclerosis. Acta Neurol Scand 1992;85:107-109.

[12] Willer CJ, Dyment DA, Sadovnick AD, Rothwell PM, Murray TJ, Ebers GC, et al. Timing of birth and risk of multiple sclerosis: population-based study. BMJ 2005;330:120.

[13] Matsuoka T, Matsushita T, Osoegawa M, Kawano Y, Minohara M, Mihara F, et al. Association of the HLA- DRB1 alleles with characteristic MRI features of Asian multiple sclerosis. Mult Scler 2008;14:1181-1190.

[14] Wiberg M, Templer DI. Season of birth in multiple sclerosis in Sweden: replication of Denmark findings. J Orthomol Med 1994;9:71-74.

[15] Sadovnick AD, Yee IM. Seasons of birth in multiple sclerosis. Acta Neurol Scand 1994;89:190-191. 
[16] Salemi G, Ragonese P, Aridon P, Reggio A, Nicoletti A, Buffa D, et al. Is season of birth associated with multiple sclerosis? Acta Neurol Scand 2000;101:381-383.

[17] Bharanidharan P. Monthly distribution of multiple sclerosis patients' births. Int J Biometeorol 1997;40:117-118.

[18] Kimura T, Miura T. Multiple sclerosis, amyotrophic lateral scrlerosis and birth season. Igaku To Seibutsugaku 1983;107:77-80.

[19] Staples J, Ponsonby AL, Lim L. Low maternal exposure to ultraviolet radiation in pregnancy, month of birth, and risk of multiple sclerosis in offspring: longitudinal analysis. BMJ 2010;340:c1640.

[20] Procopio M, Marriott PK, Williams P. Season of birth: An etiological implications for epilepsy. Seizure 1997;6:99-105.

[21] Procopio M, Marriott PK. Seasonality of birth in epilepsy: a Danish study. Acta Neurol Scand 1998;98:297-301.

[22] Ajdacic-Gross V, Wang J, Gutzwiller F. Season of birth in amyotrophic lateral sclerosis. Eur J Epidemiol 1998;14:359-361.

[23] Shibasaki H, McDonald WI, Kuroiwa Y. Racial modification of clinical picture of multiple sclerosis: comparison between British and Japanese patients. J Neurol Sci 1981;49:253-271.

[24] Lennon VA, Wingerchuk DM, Kryzer TJ, Pittock SJ, Lucchinetti CF, Fujihara K, et al. A 
serum autoantibody marker of neuromyelitis optica: distinction from multiple sclerosis. Lancet 2004;364:2106-2112.

[25] Lennon VA, Kryzer TJ, Pittock SJ, Verkman AS, Hinson SR. IgG marker of optic-spinal multiple sclerosis binds to the aquaporin-4 water channel. J Exp Med 2005;202:473-477.

[26] Ishizu T, Kira J, Osoegawa M, Fukazawa T, Kikuchi S, Fujihara K, et al. Heterogeneity and continuum of multiple sclerosis phenotypes in Japanese according to the results of the fourth nationwide survey. J Neuol Sci 2009;280:22-28.

[27] Osoegawa M, Kira J, Fukazawa T, Fujihara K, Kikuchi S, Matsui M, et al. Temporal changes and geographical differences in multiple sclerosis phenotypes in Japanese: nationwide survey results over 30 years. Mult Scler 2009;15:159-173.

[28] Vital statistics for 100 years edited by Ministry of Health and Welfare in Japan. Tokyo: The Information Department of Ministry of Health and Welfare Minister's Secretariat, Japanese Government, 2000.

[29] Japan Meteorological Agency Online. www.jma.go.jp/jma/index.html (accessed 9 Mar 2012).

[30] Vieth R, Cole DE, Hawker GA, Trang HM, Rubin LA. Wintertime vitamin D insufficiency is common in young Canadian women, and their vitamin D intake does not prevent it. Eur J Clin Nutr 2001;55:1901-1907. 
Table 1. Total number of births in Japan and its monthly distribution in 1964 and 1957

\begin{tabular}{|c|c|c|}
\hline & $\begin{array}{l}\text { Reference population for } \\
\text { LESCLs (-) group }\end{array}$ & $\begin{array}{l}\text { Reference population for } \\
\text { LESCLs (+) group }\end{array}$ \\
\hline Month & $\begin{array}{l}\text { All births in } 1964 \\
(n=1,716,761)\end{array}$ & $\begin{array}{l}\text { All births in } 1957 \\
(\mathrm{n}=1,566,713)\end{array}$ \\
\hline Jan & 162,209 & 173,807 \\
\hline Feb & 144,454 & 140,230 \\
\hline Mar & 148,384 & 141,302 \\
\hline Apr & 147,115 & 135,916 \\
\hline May & 137,133 & 123,946 \\
\hline Jun & 129,003 & 115,280 \\
\hline Jul & 142,853 & 125,564 \\
\hline Aug & 142,802 & 126,730 \\
\hline Sep & 141,225 & 119,002 \\
\hline Oct & 139,839 & 118,866 \\
\hline Nov & 134,631 & 120,378 \\
\hline Dec & 147,113 & 125,692 \\
\hline
\end{tabular}


Table 2. LESCLs (-) patients $(\mathrm{n}=906)$. Observed and expected births in each month

\begin{tabular}{|c|c|c|c|c|c|}
\hline $\begin{array}{c}\text { Month of } \\
\text { birth }\end{array}$ & $\begin{array}{l}\text { Estimated } \\
\text { month of } \\
\text { conception }\end{array}$ & $\begin{array}{c}\text { Observed } \\
\text { births }\end{array}$ & $\begin{array}{c}\text { Expected } \\
\text { births }\end{array}$ & $\begin{array}{c}\text { Ratio, } \\
\text { Observed/ } \\
\text { Expected }\end{array}$ & $\begin{array}{c}\text { Chi-square } \\
\text { test, } \mathrm{p}\end{array}$ \\
\hline Jan & Apr & 104 & 86 & 1.21 & 0.038 \\
\hline Feb & May & 74 & 76 & 0.97 & 0.78 \\
\hline Mar & Jun & 82 & 78 & 1.05 & 0.66 \\
\hline Apr & Jul & 75 & 78 & 0.96 & 0.74 \\
\hline May & Aug & 55 & 72 & 0.76 & 0.033 \\
\hline Jun & Sep & 86 & 68 & 1.26 & 0.024 \\
\hline Jul & Oct & 69 & 75 & 0.92 & 0.43 \\
\hline Aug & Nov & 89 & 75 & 1.19 & 0.10 \\
\hline Sep & Dec & 72 & 75 & 0.96 & 0.74 \\
\hline Oct & Jan & 59 & 74 & 0.80 & 0.07 \\
\hline Nov & Feb & 61 & 71 & 0.86 & 0.21 \\
\hline Dec & Mar & 80 & 78 & 1.03 & 0.78 \\
\hline
\end{tabular}


Table 3. LESCLs $(+)$ patients $(\mathrm{n}=307)$. Observed and expected births in each month

\begin{tabular}{|c|c|c|c|c|c|}
\hline $\begin{array}{c}\text { Month of } \\
\text { birth }\end{array}$ & $\begin{array}{l}\text { Estimated } \\
\text { month of } \\
\text { conception }\end{array}$ & $\begin{array}{c}\text { Observed } \\
\text { births }\end{array}$ & $\begin{array}{c}\text { Expected } \\
\text { births }\end{array}$ & $\begin{array}{c}\text { Ratio, } \\
\text { Observed/ } \\
\text { Expected }\end{array}$ & $\begin{array}{c}\text { Chi-square } \\
\text { test, } \mathrm{p}\end{array}$ \\
\hline Jan & Apr & 36 & 34 & 1.06 & 0.72 \\
\hline Feb & May & 26 & 27 & 0.96 & 0.77 \\
\hline Mar & Jun & 25 & 28 & 0.89 & 0.58 \\
\hline Apr & Jul & 23 & 27 & 0.85 & 0.45 \\
\hline May & Aug & 21 & 24 & 0.88 & 0.49 \\
\hline Jun & Sep & 19 & 23 & 0.83 & 0.42 \\
\hline Jul & Oct & 24 & 25 & 0.96 & 0.89 \\
\hline Aug & Nov & 29 & 25 & 1.16 & 0.38 \\
\hline Sep & Dec & 29 & 23 & 1.26 & 0.21 \\
\hline Oct & Jan & 24 & 23 & 1.04 & 0.87 \\
\hline Nov & Feb & 21 & 24 & 0.88 & 0.57 \\
\hline Dec & Mar & 25 & 25 & 1.00 & 0.94 \\
\hline
\end{tabular}


Table 4. LESCLs (-) males $(\mathrm{n}=250)$. Observed and expected births in each month

\begin{tabular}{|c|c|c|c|c|c|}
\hline $\begin{array}{c}\text { Month of } \\
\text { birth }\end{array}$ & $\begin{array}{l}\text { Estimated } \\
\text { month of } \\
\text { conception }\end{array}$ & $\begin{array}{c}\text { Observed } \\
\text { births }\end{array}$ & $\begin{array}{c}\text { Expected } \\
\text { births }\end{array}$ & $\begin{array}{c}\text { Ratio, } \\
\text { Observed/ } \\
\text { Expected }\end{array}$ & $\begin{array}{c}\text { Chi-square } \\
\text { test, } \mathrm{p}\end{array}$ \\
\hline Jan & Apr & 25 & 24 & 1.04 & 0.77 \\
\hline Feb & May & 15 & 21 & 0.71 & 0.16 \\
\hline Mar & Jun & 13 & 22 & 0.59 & 0.05 \\
\hline Apr & Jul & 20 & 21 & 0.95 & 0.75 \\
\hline May & Aug & 23 & 20 & 1.15 & 0.48 \\
\hline Jun & Sep & 29 & 19 & 1.53 & 0.014 \\
\hline Jul & Oct & 19 & 21 & 0.90 & 0.67 \\
\hline Aug & Nov & 23 & 21 & 1.10 & 0.61 \\
\hline Sep & Dec & 23 & 21 & 1.10 & 0.58 \\
\hline Oct & Jan & 17 & 20 & 0.85 & 0.44 \\
\hline Nov & Feb & 19 & 20 & 0.95 & 0.87 \\
\hline Dec & Mar & 24 & 21 & 1.14 & 0.55 \\
\hline
\end{tabular}


Table 5. LESCLs (-) females ( $\mathrm{n}=656)$. Observed and expected births in each month

\begin{tabular}{|c|c|c|c|c|c|}
\hline $\begin{array}{c}\text { Month of } \\
\text { birth }\end{array}$ & $\begin{array}{l}\text { Estimated } \\
\text { month of } \\
\text { conception }\end{array}$ & $\begin{array}{c}\text { Observed } \\
\text { births }\end{array}$ & $\begin{array}{c}\text { Expected } \\
\text { births }\end{array}$ & $\begin{array}{c}\text { Ratio, } \\
\text { Observed/ } \\
\text { Expected }\end{array}$ & $\begin{array}{c}\text { Chi-square } \\
\text { test, } \mathrm{p}\end{array}$ \\
\hline Jan & Apr & 79 & 62 & 1.27 & 0.023 \\
\hline Feb & May & 58 & 55 & 1.05 & 0.69 \\
\hline Mar & Jun & 69 & 57 & 1.21 & 0.08 \\
\hline Apr & Jul & 56 & 56 & 1.00 & 0.97 \\
\hline May & Aug & 32 & 52 & 0.62 & 0.003 \\
\hline Jun & Sep & 57 & 49 & 1.16 & 0.25 \\
\hline Jul & Oct & 50 & 55 & 0.91 & 0.51 \\
\hline Aug & Nov & 66 & 55 & 1.20 & 0.10 \\
\hline Sep & Dec & 49 & 54 & 0.91 & 0.48 \\
\hline Oct & Jan & 42 & 53 & 0.79 & 0.10 \\
\hline Nov & Feb & 42 & 51 & 0.82 & 0.17 \\
\hline Dec & Mar & 56 & 56 & 1.00 & 0.97 \\
\hline
\end{tabular}


Table 6. LESCLs $(-)$ northern-born patients $(\mathrm{n}=306)$. Observed and expected births in each month

\begin{tabular}{|c|c|c|c|c|c|}
\hline $\begin{array}{c}\text { Month of } \\
\text { birth }\end{array}$ & $\begin{array}{l}\text { Estimated } \\
\text { month of } \\
\text { conception }\end{array}$ & $\begin{array}{c}\text { Observed } \\
\text { births }\end{array}$ & $\begin{array}{c}\text { Expected } \\
\text { births }\end{array}$ & $\begin{array}{c}\text { Ratio, } \\
\text { Observed/ } \\
\text { Expected }\end{array}$ & $\begin{array}{c}\text { Chi-square } \\
\text { test, p }\end{array}$ \\
\hline Jan & Apr & 42 & 29 & 1.45 & 0.011 \\
\hline Feb & May & 26 & 26 & 1.00 & 0.96 \\
\hline Mar & Jun & 25 & 26 & 0.96 & 0.77 \\
\hline Apr & Jul & 30 & 26 & 1.15 & 0.43 \\
\hline May & Aug & 18 & 24 & 0.75 & 0.17 \\
\hline Jun & Sep & 26 & 23 & 1.13 & 0.51 \\
\hline Jul & Oct & 26 & 25 & 1.04 & 0.90 \\
\hline Aug & Nov & 26 & 25 & 1.04 & 0.90 \\
\hline Sep & Dec & 30 & 25 & 1.20 & 0.31 \\
\hline Oct & Jan & 16 & 25 & 0.64 & 0.06 \\
\hline Nov & Feb & 13 & 24 & 0.54 & 0.019 \\
\hline Dec & Mar & 28 & 26 & 1.08 & 0.71 \\
\hline
\end{tabular}


Table 7. LESCLs $(-)$ southern-born patients $(n=405)$. Observed and expected births in each month

\begin{tabular}{|c|c|c|c|c|c|}
\hline $\begin{array}{c}\text { Month of } \\
\text { birth }\end{array}$ & $\begin{array}{l}\text { Estimated } \\
\text { month of } \\
\text { conception }\end{array}$ & $\begin{array}{c}\text { Observed } \\
\text { births }\end{array}$ & $\begin{array}{c}\text { Expected } \\
\text { births }\end{array}$ & $\begin{array}{c}\text { Ratio, } \\
\text { Observed/ } \\
\text { Expected }\end{array}$ & $\begin{array}{c}\text { Chi-square } \\
\text { test, p }\end{array}$ \\
\hline Jan & Apr & 40 & 38 & 1.05 & 0.76 \\
\hline Feb & May & 33 & 34 & 0.97 & 0.84 \\
\hline Mar & Jun & 41 & 35 & 1.17 & 0.28 \\
\hline Apr & Jul & 30 & 35 & 0.86 & 0.40 \\
\hline May & Aug & 21 & 32 & 0.66 & 0.038 \\
\hline Jun & Sep & 37 & 30 & 1.23 & 0.21 \\
\hline Jul & Oct & 32 & 34 & 0.94 & 0.75 \\
\hline Aug & Nov & 42 & 34 & 1.24 & 0.13 \\
\hline Sep & Dec & 33 & 33 & 1.00 & 0.95 \\
\hline Oct & Jan & 28 & 33 & 0.85 & 0.36 \\
\hline Nov & Feb & 31 & 32 & 0.97 & 0.88 \\
\hline Dec & Mar & 37 & 35 & 1.06 & 0.68 \\
\hline
\end{tabular}

